\title{
A qualitative study on the diversity and conservation perspectives of pteridophytic flora in homegarden ecosystems in Polgolla in Kandy district, Sri Lanka
}

\author{
Daulagala P.W.H.K.P. ${ }^{{ }^{*}}$, Adikari A.M.N.N.S. ${ }^{2} \&$ Dissanayake K.U.N. ${ }^{2}$ \\ ${ }^{1}$ Department of Botany, Faculty of Natural Sciences, Kandy Regional Centre, The Open University of Sri Lanka, Polgolla, \\ Sri Lanka. \\ ${ }^{2}$ Faculty of Natural Sciences, Kandy Regional Centre, The Open University of Sri Lanka, Polgolla, Sri Lanka
}

\begin{abstract}
Pteridophytes are of minor economic significance to humankind as compared to other groups of plants, especially angiosperms. However, many of them are horticulturally desirable and used for decorations and ornamental purposes and some also as medicines and food. In the present study, the diversity, distribution and conservation perspectives of pteridophytic flora in homegarden ecosystems in the Polgolla Grama Niladhari Division (PGND), Kandy district, Sri Lanka, were investigated. All conceivable habitats of pteridophytes within homegardens and suburb areas in the PGND were visited frequently over a period of one year and representative samples were collected and preserved as herbarium specimens. The species collected were identified using the "Revised Handbook to the Flora of Ceylon" (Vol. XV and XVI) and verified with the specimens deposited at the Herbarium, National Botanic Gardens, Peradeniya, Sri Lanka. The study found 32 species of pteridophytes belonging to 12 families in homegardens and suburbs of three villages in the study area namely Megodagama, Egodagama and Gangewattegama. Although the importance and the conservation measures of pteridophytes have not been understood by the residents, many pteridophytes have been commonly grown as ornamental, crop and medicinal plants in their homegardens. This preliminary survey highlights the species richness of pteridophytes and the importance of conservation of existing species in PGND.
\end{abstract}

Received: 17 Sep 2018

Accepted: 13 Aug 2019

Key words:

Biological diversity;

Conservation;

Homegardens;

Pteridophytes

*Corresponding author: pdaulagala@yahoo.com

https://orcid.org/00000002-4240-3241

Tel: 0812494495-7

\section{Introduction}

Pteridophytes represent an important group of plants in the plant kingdom. Sri Lanka is popular among the Asian countries as an island having exceptionally high level of species diversity and endemicity of pteridophytes and this is largely due to the country being an island. A total of 348 pteridophyte species from 30 families have been recorded from Sri Lanka of which 50 are reported to be endemic to the country (Shaffer-Fehre, 2006).

Studies on pteridophytic flora in Sri Lanka had commenced in the late $18^{\text {th }}$ and early $19^{\text {th }}$ centuries and have basically been focused on cataloguing of genera and species based on the taxonomic studies and the preparation of species inventories for selected ecosystems. Followed research work on pteridophytes continued from the mid-1950s to 1982 included cytological studies and monograph preparations (Manton \& Sledge, 1954; Sledge, 1982). With the aim of utilization and in-situ and ex-situ conservation of ferns in Sri Lanka, many Sri Lankan scientists extended their research work to encompass the aspects of ecology, genetics and reproductive biology of some pteridophytes as well as their ethnobotanical uses, domestication and conservation measures (Ranil et al., 2010a, 2010b, 2011).

This is an open-access article distributed under the terms of the Creative Commons Attribution 4.0 International $\underline{\text { License, }}$, which permits unrestricted use, distribution and reproduction in any medium provided the original author and source are credited. 
Pteridophytes are non-flowering seedless vascular plants growing densely in moist shady habitats in temperate and tropical forests. The majority of them are terrestrial, but some are epiphytic while others are lithophytic or hydrophytic. Pteridophytes are of minor economic significance to mankind as compared to other groups of plants, especially angiosperms. However, some pteridophytes are used for decoration and ornamental purposes and can be grown as indoor or outdoor plants under varied shade levels. In addition, some members such as Pteris vittata L. accumulates arsenic in their fronds, the first fern identified as a natural arsenic hyper accumulator (Xie et al., 2009) and so helps in environmentally friendly phytoremediation processes. Further, several species are used as medicine and food (Mannan et al., 2008).

Tropical homegardens are considered as agroecosystems which have a unique micro climate and support rich species and genetic diversity (Agbogidi \& Adolor, 2013). These gardens are not only important sources of food, fodder, firewood, medicines, spices, ornamental plants and construction materials, but are also well suited for in situ conservation of a wide range of plant genetic resources. A large number of pteridophytes are cultivated as ornamental plants in homegardens due to their aesthetic value stemming from their delicate beauty. Their elegant fronds are used for decorative purposes. Most species are shade and moisture loving and luxuriously grow within interiors of forests. However, as they are strongly adaptable to grow in different environments, sunloving species can be found growing well in tree canopies and on roadsides. Ranil and Pushpakumara (2005) documented that some of the native pteridophytes such as Asplenium nidus L., Cyathea crinita (Hook.) Copel., Cyathea walkerae (Hook.), Drynaria quercifolia (L.) J Smith, Ophioglossum pendulum L. and Huperzia sp. are grown in both outdoor and indoor environments by local communities. Ranil et al. (2015) further documented that the floriculture industry in Sri Lanka is dominated by some exotic pteridophytes such as Nephrolepis spp., Adiantum spp., Davallia spp., Asplenium spp. and Platicerum spp. Nevertheless, currently many pteridophytic species are under threat due to various anthropogenic activities such as degradation and destruction of their habitats, commercial collection, pathogens, predators and invasive species, climatic changes and environmental pollution (Arcand \& Ranker, 2008). Therefore, it is necessary to raise public awareness on sustainable utilization of the existing pteridophyte taxa, promoting ex-situ and in-situ conservation and domestication.

There are no documented information on pteridophytes in homegarden ecosystems in Sri Lanka. Therefore the primary objectives of the present study were to inventorize the diversity, distribution and conservation measures of pteridophyte taxa found in selected homegarden ecosystems in Polgolla Grama Niladhari Division and to prepare herbarium specimens for future reference.

\section{Materials and Methods}

\subsection{Study site}

The study site is approximately $1 / 2 \mathrm{~km}^{2}$ and includes three villages namely Egodagama, Gangewattegama and Megodagama in Kandy district in the Central highlands of Sri Lanka. The sampled locations are shown in Figure 1.

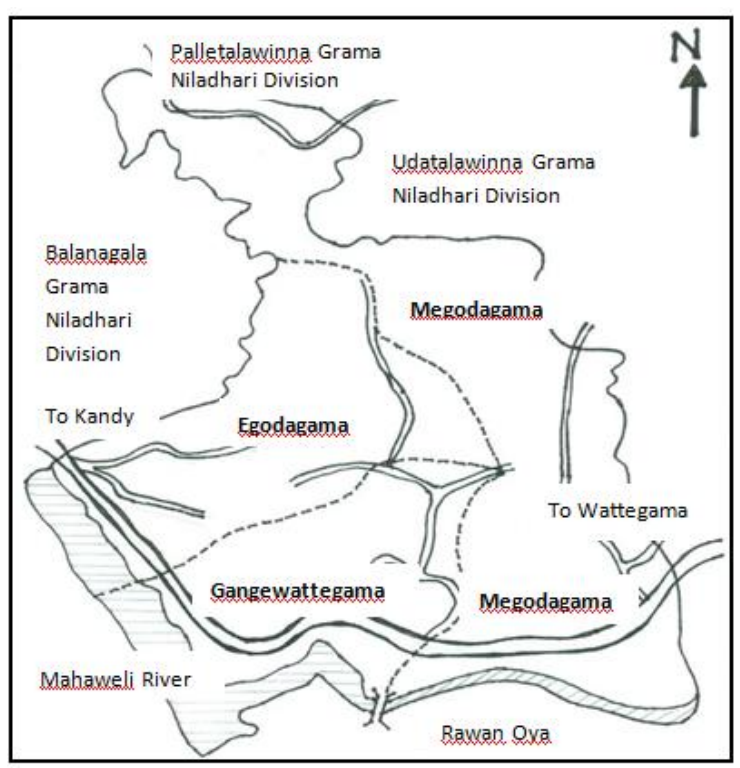

Figure 1. A sketch of the study area showing the locations of the sampling sites - Gangewattegama, Egodagama and Megodagama

The land area of Polgolla is not highly cultivated and hence most of the natural vegetation is still intact. The tropical climate with high humidity (> $0.65 \mathrm{p} / \mathrm{pet}$ ), evenly distributed rainfall throughout the year (except the dry spell during January to March), moderate temperature $\left(24{ }^{\circ} \mathrm{C}\right.$ mean annual $)$ and the soil type provide ideal conditions for a flourishing growth of pteridophytes. 


\subsection{Collection of fern species}

All localities within the homegardens in the Polgolla Grama Niladhari Division (PGND) which are ideally favourable for growth of fern flora were surveyed. During the survey, every conceivable

\subsection{Taxonomic Identification}

The species were recorded, photographed and identified using the "Revised Handbook to the Flora of Ceylon" (Vol. XV and XVI) and verified with the specimens deposited at the National Herbarium, Royal Botanic Gardens, Peradeniya, Sri Lanka.

\section{Results}

\subsection{Diversity of pteridophytes}

The survey revealed the presence of a total of 32 species in 19 genera of pteridophytes within the Polgolla Grama Niladhari Division, representing 12 families (Table 1).

Among the 12 families, Pteridaceae was the dominant family represented by 12 species, which was followed by Polypodiaceae and Nephrolepidaceae consisting of 4 species each (Figure 2). Lycophytes were represented only by two families, Lycopodiaceae and Sellaginellaceae. All species of Pteridaceae were found to be terrestrial. It was evident that the species of Pteridaceae such as Adiantum caudatum, Adiantum capillus-veneris, Nephrolepis cordifolia and Hemionitis arifolia thrive well in many homegardens, roadsides and shady and hilly areas of the study site.

\subsection{Pteridophytes with ornamental features}

Except for a few species of pteridophytes, the majority found in this study site had an ornamental value and showed many of the characteristic features of ornamental pteridophytes such as decorative fronds, attractive leaf arrangements and their overall delicate appearance. Based on the visual observation, species such as Nephrolepis cordifolia, Nephrolepis falcata, Nephrolepis hirsutula, Adiantum capillus-veneris, Pteris vittata, Pteris ensiformis and Angiopteris evecta were commonly found in many homegardens. According to the National Red List 2012 of Sri Lanka, Huperzia squarrosa was the only endemic ornamental species found and it was present only in a very few homegardens during this study. Those used as ornamentals were Nephrolepis cordifolia, Nephrolepis falcata, Adiantum capillus-veneris, Huperzia squarrosa, Asplenium nidus and Drynaria quercifolia and these plants were more frequent in homegardens. Commonly known as the bird's nest fern, Asplenium nidus was found in many homegardens growing terrestrially on the ground, in pots and rarely epiphytically on trees. Due to its entire bright green large fronds and the ability to grow well in outdoor and indoor areas, this plant was popular among the residents in the area.

\subsection{Habitat distribution of pteridophytic flora}

Pteridophytes found in this study area were in diverse habitats. Among them, 24 were terrestrial (75\%), 6 epiphytic or epilithic $(19 \%)$ and 2 aquatic species $(06 \%)$. The two aquatic fern species were from two genera namely Salvinia molesta and Azolla pinnata. The latter is the only known fern with a symbiotic association with nitrogen fixing cyanobacterium Anabaena azollae. This cyanobacterium shows a high rate of nitrogen fixation and thus this fern is suitable as a biofertilizer, limiting the use of synthetic nitrogen (Kollah et al., 2016). In addition, Azolla seems to be an excellent candidate for removal, disposal, and recovery of heavy metals from the polluted aquatic ecosystems (Arora et al. 2006). Their distribution was restricted to the patchy water bodies close to paddy fields and in some man made ponds found in homegardens. The majority was terrestrial ferns and predominantly found along roadsides (lanes, footpaths and main roads) and in some partially exposed or shady areas close to water bodies and in slopes or hilly areas of the study site.

\subsection{Conservation perspectives}

During this study, in addition to surveying the distribution of pteridophytes in the Polgolla area, some common and obvious threats for growing them in homegardens were also noted. At present some pteridophytic species recorded (e.g. Huperzia squarrosa) are listed as Endangered (EN) (MOE 2012) due to various anthropogenic activities or natural causes. However, some species (e.g. Adiantum caudatum and Adiantum capillusveneris) were typically found growing luxuriously in wet shady places in many homegardens, slopes and hilly areas, and on roadsides.

Many pteridophytes can grow in diverse soils and a small piece of a healthy rhizome is capable of producing a new plant. 


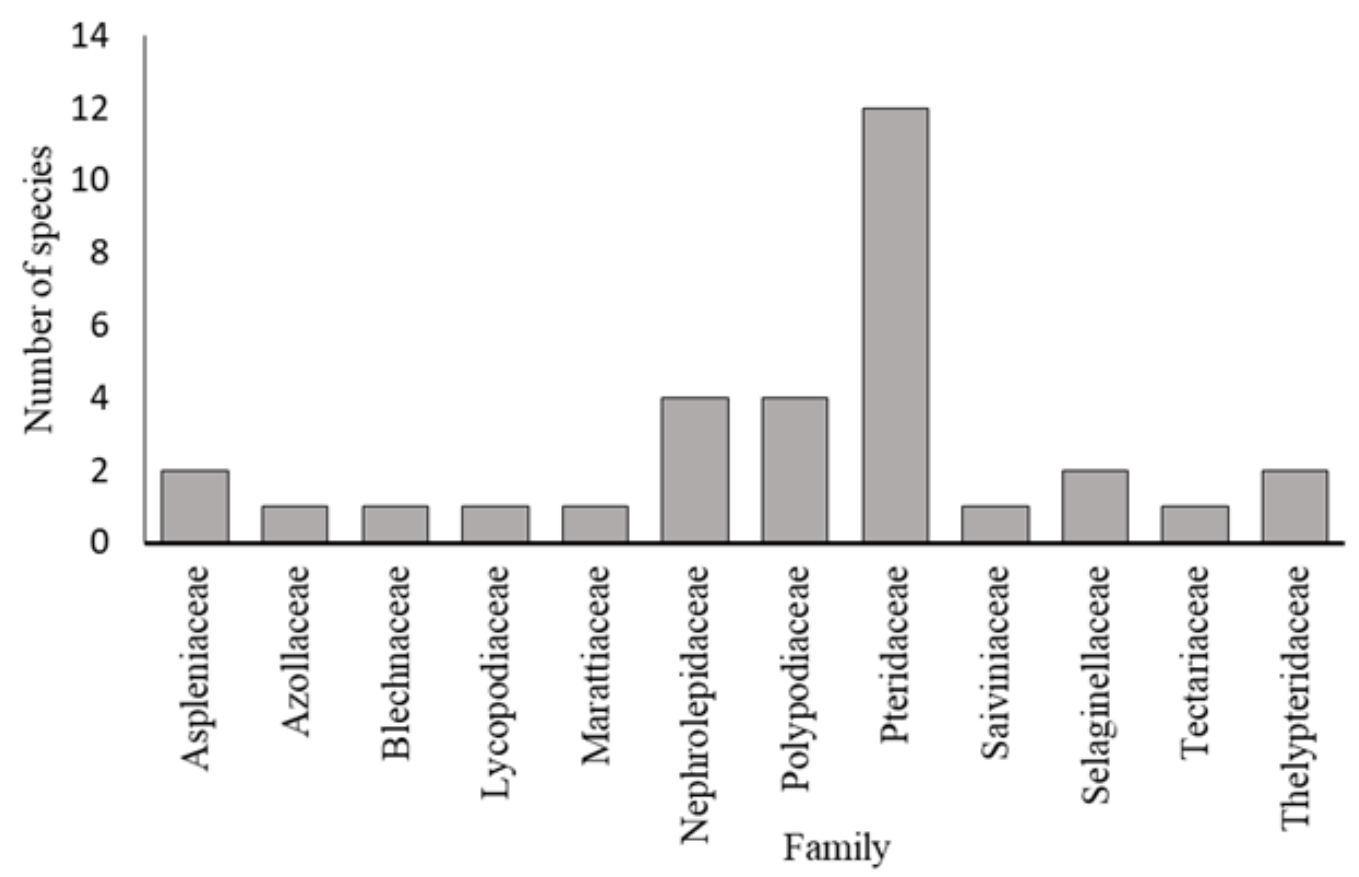

Figure 2. Families of pteridophytes recorded in the Polgolla Grama Niladhari Division and the number of species found in each family

Table 1: List of pteridophytic flora recorded in Polgolla Grama Niladhari Division, their families, common habitats and possible valued features as ornamental plants.

\begin{tabular}{|c|c|c|c|}
\hline Botanical name & Family & Habitat & $\begin{array}{l}\text { Ornamental } \\
\text { features }\end{array}$ \\
\hline Asplenium decrescens Kunze & Aspleniaceae & $\mathrm{EP} / \mathrm{EL}$ & $\mathrm{BP}, \mathrm{DF}, \mathrm{PP}$ \\
\hline Asplenium nidus L. & Aspleniaceae & $\mathrm{EP} / \mathrm{EL}$ & $\mathrm{DF}, \mathrm{PP}$ \\
\hline Azolla pinnata $\mathrm{R} . \mathrm{Br}$. & Azollaceae & A & - \\
\hline Blechnum orientale L. & Blechnaceae & $\mathrm{TE}$ & $\mathrm{BP}, \mathrm{DF}, \mathrm{PP}$ \\
\hline Huperzia squarrosa (G. Forst.) Trevis. & Lycopodiaceae & $\mathrm{EP} / \mathrm{EL}$ & $\mathrm{HP}$ \\
\hline Angiopteris evecta ( Forst.) Hoffm. & Marattiaceae & $\mathrm{TE}$ & $\mathrm{BP}, \mathrm{DF}, \mathrm{PP}$ \\
\hline Nephrolepis biserrata (Sw.) Schott & Nephrolepidaceae & TE & $\mathrm{BP}, \mathrm{DF}, \mathrm{PP}$ \\
\hline Nephrolepis cordifolia (L.) C.Presl & Nephrolepidaceae & TE & $\mathrm{BP}, \mathrm{DF}, \mathrm{PP}$ \\
\hline Nephrolepis falcata (Cav.) C.Chr. & Nephrolepidaceae & $\mathrm{TE}$ & $\mathrm{BP}, \mathrm{DF}, \mathrm{PP}$ \\
\hline Nephrolepis hirsutula (G. Forst.) C.Presl & Nephrolepidaceae & $\mathrm{TE}$ & $\mathrm{BP}, \mathrm{DF}, \mathrm{PP}$ \\
\hline Drynaria quercifolia (L.) J. Smith & Polypodiaceae & $\mathrm{EP} / \mathrm{EL}$ & $\mathrm{DF}, \mathrm{HP}$ \\
\hline Pyrrosia heterophylla (L.) Price & Polypodiaceae & $\mathrm{EP} / \mathrm{EL}$ & $\mathrm{DF}$ \\
\hline Pyrrosia lanceolata (L.) Farw. & Polypodiaceae & $\mathrm{EP} / \mathrm{EL}$ & DF \\
\hline Microsorum scolopendrium (Burm. f.) Copel. & Polypodiaceae & TE & $\mathrm{DF}, \mathrm{PP}$ \\
\hline Adiantum caudatum $\mathrm{L}$. & Pteridaceae & TE & $\mathrm{BP}, \mathrm{DF}, \mathrm{PP}$ \\
\hline Adiantum capillus-veneris L. & Pteridaceae & TE & $\mathrm{BP}, \mathrm{DF}, \mathrm{PP}$ \\
\hline Adiantum hispidulum $\mathrm{Sw}$. & Pteridaceae & TE & $\mathrm{BP}, \mathrm{DF}, \mathrm{PP}$ \\
\hline Adiantum diaphanum Blume & Pteridaceae & TE & $\mathrm{BP}, \mathrm{DF}, \mathrm{PP}$ \\
\hline Adiantum latifolium Lam. & Pteridaceae & TE & $\mathrm{BP}, \mathrm{DF}, \mathrm{PP}$ \\
\hline Pityrogramma dealbata $\quad$ (C. Presl) Tryon & Pteridaceae & TE & $\mathrm{BP}, \mathrm{DF}, \mathrm{PP}$ \\
\hline $\begin{array}{l}\text { Hemionitis arifolia (Burm.) T. Moore } \\
\text { (Syn. Parahemionitis arifolia (Burm.) Panigrahi) }\end{array}$ & Pteridaceae & TE & $\mathrm{BP}, \mathrm{DF}, \mathrm{PP}$ \\
\hline Doryopteris concolor (Langsd. \& Fisch) Kuhn & Pteridaceae & TE & $\mathrm{BP}, \mathrm{DF}, \mathrm{PP}$ \\
\hline Pteris ensiformis Burm.f. & Pteridaceae & TE & $\mathrm{BP}, \mathrm{DF}, \mathrm{PP}$ \\
\hline Pteris multiaurita J. Agardh & Pteridaceae & TE & $\mathrm{BP}, \mathrm{DF}, \mathrm{PP}$ \\
\hline Pteris quadriaurita Retz & Pteridaceae & $\mathrm{TE}$ & $\mathrm{BP}, \mathrm{DF}, \mathrm{PP}$ \\
\hline Pteris vittata $\mathrm{L}$. & Pteridaceae & TE & $\mathrm{BP}, \mathrm{DF}, \mathrm{PP}$ \\
\hline Salvinia molesta Mitch. & Salviniaceae & A & - \\
\hline
\end{tabular}


Selaginella crassipes Spring

Selaginella sp.

Tectaria zeilanica (Houtt) Sledge

Cyclosorus tylodes (kunze)

Christella dentata (Forssk.) Brownsey \& Jermy
Selaginellaceae

Selaginellaceae

Tectariaceae

Thelypteridaceae

Thelypteridaceae
TE

TE

TE

TE

TE
DF, CR

DF, CR

BP, DF, PP

$\mathrm{BP}, \mathrm{DF}, \mathrm{PP}$

BP, DF, PP

(Habitats denoted as A - Aquatic, EP- Epiphytic, EL- Epilithic, TE- Terrestrial and ornamental features denoted as DF - Decorative fronds; PP - Pot plants; BP - Bed plants; HP - Hanging plants and CR - Creeping plants)

Since many of these plants have a rapid vegetative growth rate, most gardeners had a concern about the competition between these species and their agricultural crops for nutrients and other growth requirements and are hence considered as a major threat to their economically important crops.

As such competitors can cause damage through displacement of some desirable plants in homegardens, many gardeners used to control the growth or eliminate those that are deemed to be aggressive in growth. Asplenium nidus was given prominence as an ornamental plant and is typically found to be grown in pots, particularly when the space is limited. However, unfortunately, assuming that species such as Asplenium, Drynaria and Pyrrosia growing as epiphytes on tree trunks and branches as parasitic pteridophytes (but not so and therefore do not harm the hosts), some gardeners have taken steps to eradicate them from their homegardens. Therefore, conservation of many pteridophytic species is a vital factor and it is almost entirely dependent upon the protection of their habitats. In addition to habitat loss, spreading of invasive plant species, environmental pollution and erosion of soil can be considered as some of the common threats affecting the pteridophytic diversity in the study area. As utilization of ferns is not properly regulated, research on ex-situ or in-situ conservation of these species may be critical.

\section{Discussion}

Ornamental plants are plants that are grown for decorative purposes in gardens and landscapes for their beautiful flowers and/or elegant leaves (Kochhar, 2009).Though pteridophytes are nonflowering plants, due to the attractiveness and elegance of their fronds as well as their ability to grow well in different habitats where shade and moisture is prevalent, the majority of them can be used as ornamental plants in floriculture industry in Sri Lanka. Further, in comparison to other plant taxa, pteridophytes show many other favourable features important in the floriculture industry such as year round production, the lower effort needed for production and thus the lower labour cost, the lower susceptibility to pests and diseases and the ability to grow on the ground, in pots and as epiphytes on tree trunks and hanging baskets.

The species richness of pteridophytes along shady footpaths and narrow lanes connecting neighbouring houses and those leading to paddyfields and other croplands was considerably high compared to that along the main roads. These species were seen to grow well in moist and shady places in the gardens where other plants generally cannot grow. In terms of abundance, this study recorded that the species such as Adiantum caudatum, Adiantum capillus-veneris, Hemionitis arifolia, Blechnum orientale, Selaginella crassipes and Nephrolepis biserrata were predominant in many homegardens and other shady areas as well as along roadsides in all three villages and were commonly recorded in varied habitats such as on the ground, in pots, as epiphytes tied to tree trunks and in hanging pots. As reported by Arcand \& Ranker (2008), the main threat for the pteridophytes are habitat degradation and habitat destruction, commercial collection, pathogens and predators, climate or microclimate change, environmental pollution and competition with invasive species.

Generally a homegarden is an area of land around a family home, where fruit trees, vegetables, foliage and flowering plants and medicinal plants etc. are purposefully cultivated. Many homegardens located within the study area displayed a mixture of different types of such plants, with fruit trees and other agricultural crops being predominant. In such places, the existence of pteridophytic species was highly limited, since priority was given for optimization of economically important agricultural crops, in which the harvest could be used for home consumption or for selling in small quantities for an additional income. Under such situations, steps have to be taken for conservation of at least horticulturally desirable species in the Botanic Gardens in different parts of the country, before many of them become endangered or permanently extinct.

Due to the favourable climatic conditions, there has been an increasing demand particularly for growing ornamental plants (flowering and foliage plants) in both urban and rural areas in Kandy. The 
ornamental nursery business has therefore developed on a large scale in areas in and around the Kandy city. Among the different varieties of foliage plants, a large number of pteridophytes are considered to be highly prized for both indoor and outdoor gardening. Planting pteridophytes, whether indoors or outdoors need less attention compared to flowering plants. Hence most of the nursery owners and suppliers collect large quantities of such species for a low price from gardeners which is seen as a threat to rare species as well as for those with small populations.

\section{Conclusions}

A total of 32 species in 19 genera of pteridophytes were collected within the Polgolla Grama Niladhari Division, which belonged to 12 families. Pteridaceae, represented by 12 species was found to be the dominant family among them. This was followed by Polypodiaceae and Nephrolepidaceae consisting of 4 species each. Adiantum is the largest genus with as many as five species being recorded within the study area, followed by Nephrolepis and Pteris each represented by four species. Currently, many pteridophytic flora are under threat even in rural areas, as a result of anthropogenic activities. This preliminary survey in PGND provides useful information as to the further steps that could be taken to maintain and conserve the respective habitats of pteridophytes in the study area.

\section{Acknowledgement}

The authors acknowledge permission granted to use to herbarium of the National Botanic Gardens, Peradeniya, Sri Lanka. Guidance and valuable comments given by Dr. R.H.G. Ranil, Department of Crop Science, Faculty of Agriculture, University of Peradeniya, Sri Lanka are highly appreciated.

\section{References}

Agbogidi, O.M., Adolor, E.B. (2013) Home gardens in the maintenance of biological diversity. Applied Science Reports 1: 19-25.

Arcand, N.N., Ranker, T.A. (2008) Conservation Biology. In: T.A. Ranker and C.H. Haufler (eds), Biology and Evolution of Ferns and Lycophytes. pp. 257-283, Cambridge University Press, Cambridge.

Arora, A., Saxena, S., Sharma, D.K. (2006) Tolerance and phytoaccumulation of chromium by three Azolla species. World Journal of Microbiology \& Biotechnology 22: 97-100.
Kochhar, S.L. (2009) Economic Botany in the Tropics. $3^{\text {rd }}$ Ed. Macmillan Publishers, India Ltd., New Delhi.

Kollah, B., Patra, A.K., Mohanty, S.R. (2016) Aquatic microphylla Azolla: a perspective paradigm for sustainable agriculture, environment and global climate change. Environmental Science and Pollution Research 23: 4358-4369.

Mannan, M.M., Maridas, M., Victor, B. (2008) A review of the potential uses of ferns. Ethnobotanical Leaflets 12: 281-285.

Manton, I., Sledge, W.A. (1954) Observations on the cytological and taxonomy of the Pteridophyte flora of Ceylon. Philosophical Transactions of the Royal Society of London, Series B 238: 127-185.

MOE 2012. The National Red List 2012 of Sri Lanka; Conservation status of the Fauna and Flora. Ministry of Environment, Colombo, Sri Lanka viii + 476pp.

Ranil, R.H.G., Pushpakumara, D.K.N.G. (2005) Uses of Pteridophyte flora in Sri Lanka. Proceedings of the Tenth Annual Forestry and Environment Symposium, Department of Forestry and Environmental Science, University of Sri Jayawardenapura, p. 28.

Ranil, R.H.G., Pushpakumara, D.K.N.G., Janssen, T., Wijesundara, D.S.A., Dhanasekara, D.M.U.B. (2010a) Cyathea srilankensis Ranil: a new fern species from Sri Lanka. American Fern Journal 100: 39-44.

Ranil, R.H.G., Pushpakumara, D.K.N.G., Janssen, T., Fraser-Jenkins, C.R., Wijesundara, D.S.A. (2010b) Cyathea sledgei Ranil (Cyatheaceae): A new species of tree-fern from Sri Lanka. Fern Gazette by British Pteridological Society. United Kingdom 18: 318-325.

Ranil, R.H.G., Pushpakumara, D.K.N.G., Janssen, T., Fraser-Jenkins, C.R., Wijesundara, D.S.A. (2011) Conservation priorities of tree ferns of Sri Lanka. Taiwania 56(3): 201 - 209.

Ranil, R.H.G., Beneragama, C.K., Pushpakumara, D.K.N.G., Wijesundara, D.S.A. (2015) Ornamental pteridophytes: an underexploited opportunity for the Sri Lankan floriculture industry. Journal of the National Science Foundation of Sri Lanka 43(4): 293-301.

Shaffer-Fehre, M. (ed.) (2006) A Revised Handbook of the Flora of Ceylon, volume 15: Pteridophyta (Ferns and Fern Allies). Amrind Publishing Company Private Limited, New Delhi, India. 
Sledge, W.A. (1982) An annotated check-list of the Pteridophyta of Ceylon. Biological Journal of Linnean Society 84: 1-30.

Xie, Q.E., Yan, X.L., Liao, X.Y., Li, X. (2009) The arsenic hyperaccumulator fern Pteris vittata L. Environmental Science and Technology 43: 8488-8495. 